DOI: 10.17516/1997-1397-2020-13-1-97-103

УДК 538.9

\title{
Application of DMA 242 C for Quasi-Static Measurements of Piezoelectric Properties of Solids
}

\author{
Pavel P. Turchin* \\ Siberian Federal University \\ Krasnoyarsk, Russian Federation \\ Kirensky Institute of Physics \\ Federal Research Center KSC SB RAS \\ Krasnoyarsk, Russian Federation \\ Vladimir I. Turchin \\ Sergey V. Yurkevich \\ Pavel O. Sukhodaev \\ Irina S. Raikova \\ Siberian Federal University \\ Krasnoyarsk, Russian Federation
}

Received 09.09.2019, received in revised form 16.10.2019, accepted 06.12.2019

\begin{abstract}
An experimental device for quasi-static measurements of piezoelectric moduli $d_{i j k}$, based on the possibilities of precision variations in mechanical stresses with the device DMA $242 \mathrm{C}$ in the frequency range 0-100 $\mathrm{Hz}$ has been developed. A special sample holder and a charge amplifier are used in the measuring scheme. The measurements of piezoelectric moduli values of trigonal piezoelectric single crystalls $\mathrm{La}_{3} \mathrm{Ga}_{5} \mathrm{SiO}_{14}(\mathrm{P} 321)$ and $\mathrm{YAl}_{3}\left(\mathrm{BO}_{3}\right)_{4}$ (R32), as well as hexagonal $\mathrm{ZnO}$ ( $\mathrm{P} 6{ }_{3} \mathrm{mc}$ ) have been carried out.
\end{abstract}

Keywords: piezoelectric modules, quasistatic method, multiferroics.

Citation: P.P.Turchin, V.I.Turchin, S.V.Yurkevich, P.O.Sukhodaev, I.S.Raikova, Application of DMA 242 C for Quasi-Static Measurements of Piezoelectric Properties of Solids, J. Sib. Fed. Univ. Math. Phys., 2020, 13(1), 97-103.

DOI: $10.17516 / 1997-1397-2020-13-1-97-103$.

\section{Introduction}

A wide range of piezoelectric materials applications determines the development of physical methods for the experimental determination of their piezoelectric properties [1-4]. The resonance $[1,2,5]$, ultrasonic $[2,5]$ and quasi-static $[6,7]$ methods for determining piezoelectric constants, along with measurements of direct [8] and inverse [9] piezoelectric effects in crystals are known. Depending on thermodynamic boundary conditions and point symmetry of a material, each of these methods has a set of ratios and cuts for the separate determination of piezoelectric constants. In particular, for ultrasound measurements of piezoelectric moduli $e_{i j k}$ of a number of single crystals, such an analysis is carried out in $[10,11]$. The complex of experimental tools and calculated ratios determine the accuracy and future prospects of a selected method.

The existing experimental methods are subjected to constant modifications and improvements due to the continuous development of piezoelectric applications [12], as well as appearance of new materials, for instance, multiferroics [13], and the necessity to study their magnetoelectric and other properties.

\footnotetext{
*pturchin@sfu-kras.ru

(C) Siberian Federal University. All rights reserved
} 
The possibilities for applying precision device DMA $242 \mathrm{C}$ to create periodic mechanical stresses when determining piezoelectric moduli $d_{i j k}$ by the quasi-static method are studied in this paper. The measured values of the piezoelectric constants of trigonal and hexagonal crystals are compared with the scientific literature data. The values of piezoelectric moduli of yttrium aluminum borate obtained by the authors with the application of the developed experimental method are given.

\section{Experimental quasi-static method}

DMA $242 \mathrm{C}$ device [14] provides a precise change in the applied dynamic load with a frequency of $0-100 \mathrm{~Hz}$ to the sample in the range of $0-8 \mathrm{~N}$ with simultaneous possibility to control static load in the same range. The direction of load application coincides with the vertical axis of the device pusher.

The block diagram of the experimental method with the use of DMA $242 \mathrm{C}$ for quasi-static measurements of piezoelectric moduli is given in Fig. 1. The test sample is placed in the measuring chamber of the device between two dielectric holders. The lower one is installed on the sample holder DMA 242 C 7, and the upper one is free, and the load from the device pusher is applied to it. The uniform distribution of mechanical stresses in the sample is achieved by applying lubricant between the sample and the holder. Electrodes for measuring the charge are applied on the horizontal facets of the sample for measuring the longitudinal piezoelectric effect and on the vertical ones for measuring transverse piezoelectric moduli. The electric surface charges of the piezoelectric sample under load are converted by the charge amplifier 4 to the voltage recorded by the oscilloscope 3 . The value of the measured piezoelectric modulus is determined by the equation of state, and in this experimental diagram is determined according to the ratio

$$
d_{i \lambda}=\frac{q}{F}=\frac{U S_{l}}{K_{a} F S_{e}},
$$

where $\mathrm{d}_{i \lambda}$ is the measured piezoelectric modulus, $\mathrm{q}$ is the charge on the electrodes, $\mathrm{F}$ is the dynamic force amplitude, $\mathrm{U}$ is the voltage amplitude at the output of the charge amplifier, $\mathrm{S}_{l}$ is the load application area, $\mathrm{S}_{e}$ is the surface area of the electrodes, $\mathrm{K}_{a}$ is conversion factor of the charge amplifier.

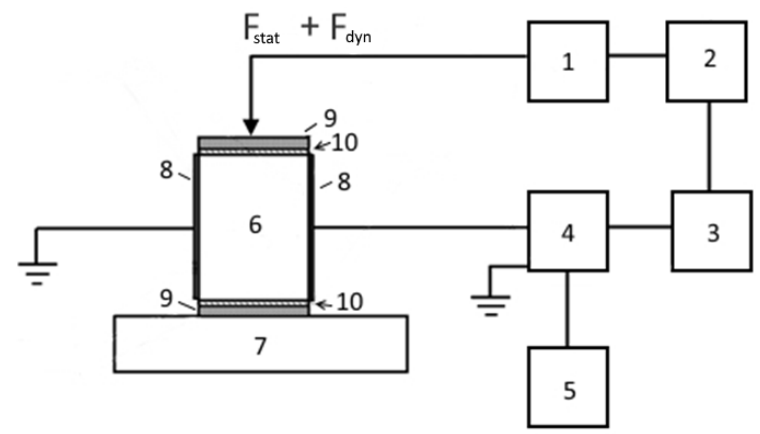

Fig. 1. Block diagram of the quasi-static method for measuring piezoelectric moduli. A variant of measurement of the transverse to the direction of the pressure of electric polarization is presented. 1 - DMA 242 C, 2 - personal computer, 3 - oscilloscope DPO 7104, 4 - charge amplifier LE-41, 5 - power supply, 6 - sample, 7 - sample holder, 8 - electrodes, 9 - dielectric holders, $10-$ lubricant layer

The accuracy of the device performance and the piezoelectric moduli measurement were controlled by measuring piezoelectric constants under conditions of different dynamic loads and 
different measuring frequencies. Fig. 2 demonstrates linear dependence of the measured charge on the magnitude of the dynamic load, and Fig, 3 shows the constancy of the determined voltage for different measurement frequencies.

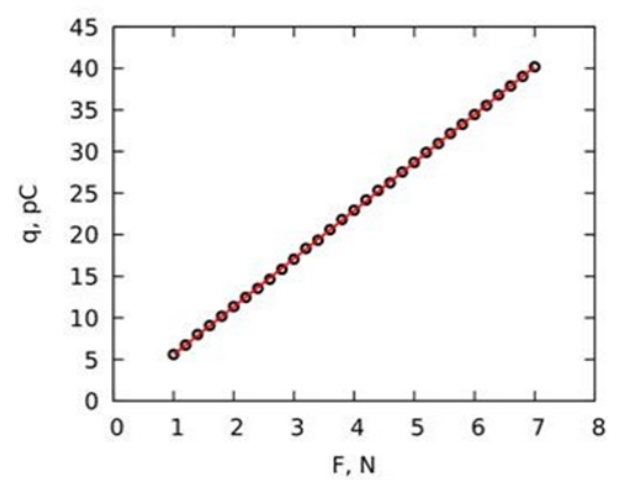

Fig. 2. Dependence of the charge values on the sample facets on the dynamic load magnitude

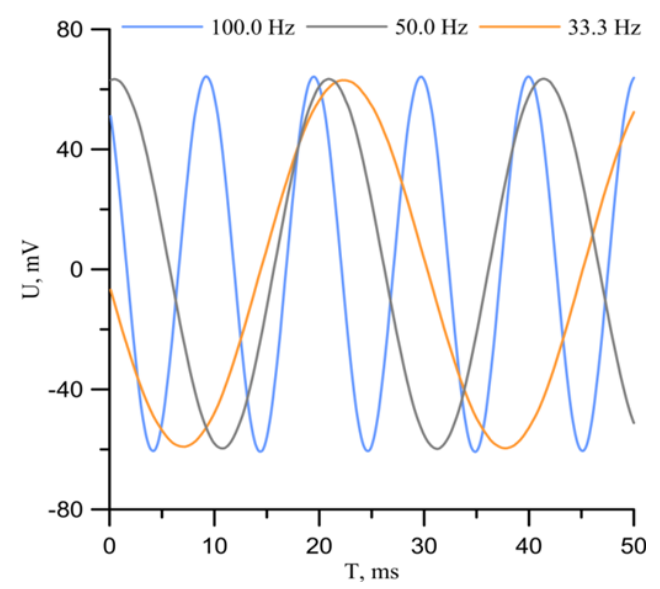

Fig. 3. Values of voltage $U$ on the sample when measuring at different frequencies

\section{Calculated ratios for determining piezoelectric moduli}

The implemented quasi-static method has been applied to determine the piezoelectric moduli $d_{i j k}$ of the well-studied single crystals of langasite $\mathrm{La}_{3} \mathrm{Ga}_{5} \mathrm{SiO}_{14}$ [12] and zincite $\mathrm{ZnO}$ [15], as well as yttrium alumoborate $\mathrm{YAl}_{3}\left(\mathrm{BO}_{3}\right)_{4}[16]$, which belongs to the rare-earth oxiborates $\mathrm{RMe}_{3}\left(\mathrm{BO}_{3}\right)_{4}$ (where $\mathrm{R}=\mathrm{Y}, \mathrm{La}-\mathrm{Lu} ; \mathrm{Me}=\mathrm{Fe}, \mathrm{Al}, \mathrm{Cr}, \mathrm{Ga}, \mathrm{Sc}$ ), but does not have a magnetic subsystem. Due to the latter circumstance, yttrium alumoborate is a kind of standard of electroelastic interaction for the whole family of oxiborates. However, there is no data on the piezoelectric properties of this single crystal in scientific literature.

Moduli $\mathrm{d}_{11}$ and $\mathrm{d}_{14}$ were determined for trigonal (point symmetry group 32 ) langasite and yttrium alumoborate, and for hexagonal $(6 \mathrm{~mm})$ zinc oxide $-\mathrm{d}_{33}, \mathrm{~d}_{31}$. The geometry of the samples required for the separate determination of these components is given in Fig. 4.

In quasi-static measurements, the longitudinal piezo modulus $\mathrm{d}_{11}$ was determined by applying mechanical compressive stress along axis $\mathrm{X}_{1}$ and registering a charge in the same direction (Fig. $4(\mathrm{a}, \mathrm{b}))$. To determine piezoelectric moduli $\mathrm{d}_{33}$ and $\mathrm{d}_{31}$, the mechanical compressive 

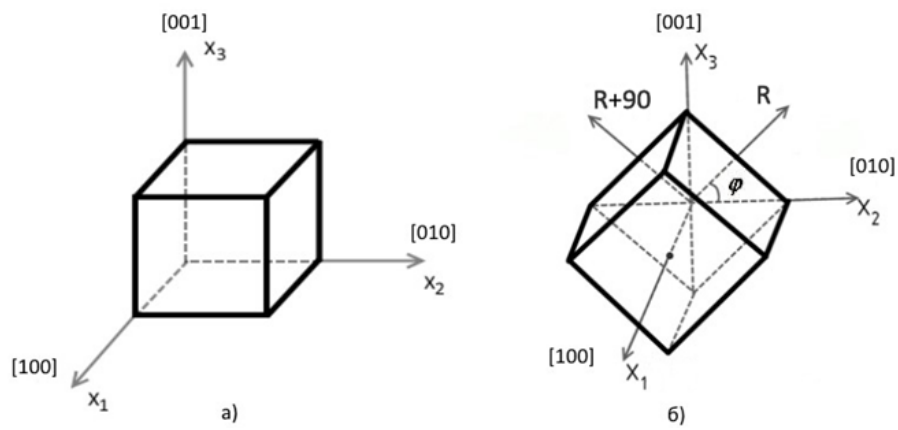

Fig. 4. Sample orientation for quasi-static measurements

stress was applied along $\mathrm{X}_{3}$, and the charge was recorded along axes $\mathrm{X}_{3}$ and $\mathrm{X}_{1}$, respectively (Fig. 4 (a)). The piezo modulus $\mathrm{d}_{14}$ was found by determining the charge in the direction of axis $\mathrm{X}_{1}$ when mechanical stresses were applied to facets $\mathrm{R}$ and $\mathrm{R}+90$ (Fig. 4 (b)). In this case, from the rule of the orthogonal tensor transformation $[17,18]$

$$
d_{i^{\prime} j^{\prime} k^{\prime}}=a_{i^{\prime} l} a_{j^{\prime} m} a_{k^{\prime} n} d_{l m n},
$$

for crystals of the point symmetry group 32 for the direction $\mathrm{R}$ we find

$$
d_{12}^{R}=d_{14} \sin \varphi \cos \varphi-d_{11} \cos ^{2} \varphi,
$$

for the direction $\mathrm{R}+90$

$$
d_{12}^{R+90}=-d_{14} \sin \varphi \cos \varphi-d_{11} \sin ^{2} \varphi .
$$

The angle $\varphi$ for langasit was 45 degrees, and for yttrium alumoborate 48.05 degrees. The sign of the piezoelectric modulus was found by determining the direction of the electric induction vector as related to the axes of the crystal-physical coordinate system, the selection rules of which are described in [18].

\section{Experimental results}

The linear dimensions of the samples were about 5-6 $\mathrm{mm}$, the accuracy of the facets' orientation was not worse than \pm 3 ', the flatness of the opposite facets was 3 microns. The positive direction of the axis $\mathrm{X}_{1}$ of the crystal-physical coordinate system for the crystals of symmetry 32 was chosen from acoustic measurements $[12,18]$, under condition that $\mathrm{C}_{14}<0$. The sign of the piezoelectric constants was controlled by the direct measurement of the piezoelectric effect. Mechanical compressive stress was considered negative. All measurements were carried out at room temperature.

The obtained values of piezoelectric moduli are summarized in the Tab. 1 and compared with the data of other authors for langasite and zinc oxide. According to the Table, the experimental values of the determined piezoelectric moduli for zinc oxide and langasite correlate with the values of the piezoelectric moduli obtained by other authors. This fact suggests the correct operation of the device for quasi-static measurements of the piezoelectric moduli with the application of DMA $242 \mathrm{C}$ and confirms the accuracy of determining piezoelectric moduli of yttrium alumoborate.

\section{Conclusion}

The carried out research has demonstrated the possibility to apply DMA 242 C to control dynamic loads on the crystal in the process of quasi-static measurements of single crystal piezo- 
Table 1. Piezoelectric moduli

\begin{tabular}{|c|c|c|c|}
\hline Modulus & $\begin{array}{l}\text { Experimental value } \\
\mathrm{d}_{i \lambda}, 10^{-12} \mathrm{C} / \mathrm{N}\end{array}$ & $\begin{array}{l}\text { Literature values } \\
\mathrm{d}_{i \lambda}, 10^{-12} \mathrm{C} / \mathrm{N}\end{array}$ & References \\
\hline \multicolumn{4}{|c|}{$\mathrm{ZnO}$} \\
\hline \multirow{4}{*}{$\mathrm{d}_{31}$} & \multirow{4}{*}{$-5.2 \pm 0.2$} & -5.12 & [19] \\
\hline & & -5.0 & [20] \\
\hline & & -5.2 & [21] \\
\hline & & -3.7 & {$[22]$} \\
\hline \multirow{4}{*}{$d_{33}$} & \multirow{4}{*}{$11.7 \pm 0.2$} & 12.3 & [19] \\
\hline & & 12.4 & [20] \\
\hline & & 10.6 & [21] \\
\hline & & 8.0 & {$[22]$} \\
\hline \multicolumn{4}{|c|}{$\mathrm{La}_{3} \mathrm{Ga}_{5} \mathrm{SiO}_{14}$} \\
\hline \multirow{4}{*}{$\mathrm{d}_{11}$} & \multirow{4}{*}{$-6.1 \pm 0.2$} & -6.16 & [23] \\
\hline & & 6.25 & {$[24]$} \\
\hline & & 6.20 & {$[25]$} \\
\hline & & 6.1 & [26] \\
\hline \multirow{3}{*}{$\mathrm{d}_{14}$} & \multirow{3}{*}{$-5.4 \pm 0.3$} & 5.36 & [23] \\
\hline & & -3.65 & {$[24]$} \\
\hline & & 5.4 & {$[26]$} \\
\hline \multicolumn{4}{|c|}{$\mathrm{YAl}_{3}\left(\mathrm{BO}_{3}\right)_{4}$} \\
\hline $\mathrm{d}_{11}$ & $-6.0 \pm 0.3$ & - & - \\
\hline $\mathrm{d}_{14}$ & $-7.2 \pm 0.4$ & - & - \\
\hline
\end{tabular}

electric moduli. This application is based on the modification of the measuring cell of the device with the use of additional dielectric sample holders, as well as on the use of the standard charge amplifier in the measuring diagram. The accuracy and repeatability of the results are based on the creation of uniform mechanical stresses in the sample. The obtained values of the piezoelectric langasite and zincite moduli correspond to scientific literature data. The device developed on the basis of DMA $242 \mathrm{C}$ was applied to determine the piezoelectric moduli of yttrium aluminum borate.

The reported study was funded by Russian Foundation for Basic Research project no. 18-42240016, Government of Krasnoyarsk Territory, Krasnoyarsk Regional Fund of Science, to the research project: "Electromechanical Properties and Anisotropy of Acoustic Wave Propagation in Yttrium Aluminoborates Single Crystals".

\section{References}

[1] W.Cady, Piezoelectricity: An Introduction to the Theory and Applications of Electromechanical Phenomena in Crystals, Moscow, Foreign Literature Publishing House, 1949 (in Russian).

[2] W.Mason, Physical Acoustics. Volume 1. Ultrasonic Instruments and Devices, Moscow, Mir, 1966 (in Russian). 
[3] A.V.Shubnikov, Piezoelectric Textures. Moscow, Leningrad, Publishing House of the Academy of Sciences of the USSR, 1946 (in Russian).

[4] R.Truell, Ultrasonic Methods in Solid State Physics, Moscow, Mir, 1972 (in Russian).

[5] K.S.Aleksandrov, B.P.Sorokin, P.P.Turchin, D.A.Glushkov, In Ferroelectrics Letters, 14(1992), no. 5-6, 115-126.

[6] V.A.Golovin, I.A.Kaplunov, O.V.Malyshkina, B.B.Ped'ko, A.A.Movchikova, Physical Bases, Research Methods and Practical Application of Piezomaterials, Moscow, Tekhnosphera, 2013 (in Russian).

[7] M.V.Bogush, Designing Piezoelectric Sensors Based On Spatial Electrothermoelastic Models, Moscow, Tekhnosphera, 2014 (in Russian).

[8] K.S.Aleksandrov et al., In Physics of the Solid State, 45(2003), no. 1, 41-45.

[9] A.L.Freidman, S.I.Popkov, S.V.Semenov, P.P.Turchin, In Technical Physics Letters, 44(2018), no. 2, 123-125. DOI: $10.1134 /$ S1063785018020074

[10] S.V.Bogdanov, Acoustic Journal, 43(1997), no. 3, 304-309.

[11] S.V.Bogdanov, Acoustic Journal, 46(2000), no. 5, 530-533. DOI: 10.1134/1.1310376

[12] K.S.Aleksandrov, B.P.Sorokin, S.I.Burkov, Effective Piezoelectric Crystals for Acoustic Electronics, Piezoelectric Devices and Sensors, Vol. 1, Novosibirsk, Publishing House of the Siberian Branch of the Russian Academy of Sciences, 2007.

[13] A.P.Pyatakov, A.K.Zvezdin, Physics-Uspekhi, 55(2012), no. 6, 557-580. DOI:/10.3367/UFNr.0182.201206b.0593

[14] Dynamic-Mechanical Analysis - DMA 242C [Electronic Resource] (Available at: http://photos.labwrench.com/equipmentManuals/7511-2751.pdf).

[15] S.Adachi, Handbook on Physical Properties of Semiconductors, Vol. 3, II-VI Compound Semiconductors - Springer Science \& Business Media, 2004.

[16] L.Zheng et al., $>1$ MW Peak Power at $266 \mathrm{~nm}$ in Nonlinear $\mathrm{YAl}_{3}\left(\mathrm{BO}_{3}\right)_{4}$ (YAB) Single Crystal, In Lasers and Electro-Optics (CLEO), 2015 Conference on. IEEE, 2015.

[17] J.Nye, Physical Properties of Crystals Their Representation by Tensors and Matrices, Clarendon Press, Oxford, 1964.

[18] Yu.I.Sirotin, M.P.Shaskol'skaya, Principles of Crystal Physics, Moscow, Nauka, 1975 (in Russian).

[19] I.B.Kobyakov, Solid State Communications, 35(1980), no. 3, 305-310.

[20] D.F.Crisler, J.J.Cupal, A.R.Moore, Dielectric, Piezoelectric, and Electromechanical Coupling Constants of Zinc Oxide Crystals, In Proc. IEEE, 1968, Vol. 56, no. 2. 225-226.

[21] H.Jaffe, D.A.Berlincourt, Piezoelectric Transducer Materials, In Proc. IEEE, 1965, Vol. 53, no. $10,1372-1386$.

[22] M.Catti, Y.Noel, R.Dovesi, Journal of Physics and Chemistry of Solids, 64(2003), no. 11, 2183-2190. 
[23] A.A.Kaminskii, I.M.Silvestrova, S.E.Sarkisov, G.A.Denisenko, Phys. Stat. Solidi (a), 80(1983), no. 2, 607-620. DOI: $10.1002 /$ pssa.2210800225

[24] J.Stade, L.Bohatỹ, M.Hengst, R.B.Heimann, Cryst. Res. Technol., 37(2002), no. 10, $1113-1120$

[25] S.Zhang et al., Journal of Applied Physics, 105(2009), no. 11, 114107.

DOI: $10.1063 / 1.3142429$

[26] I.A.Andreev, Single Crystals with Moderate and Strong Electromechanical Coupling for Acoustic Electronics and Acousto-Optics, Abstract of diss. Doct. Phys.-Math. sciences, Moscow, Sciences (04.01.07), St. Petersburg, 2007.

\title{
Применение DMA 242 C для квазистатических измерений пьезоэлектрических свойств твердых тел
}

\author{
Павел П. Турчин \\ Сибирский федеральный университет \\ Красноярск, Russian Federation \\ Институт физики им. Л. В. Киренского СО РАН \\ Красноярск, Российская Федерация \\ Владимир И. Турчин \\ Сергей В. Юркевич \\ Павел О. Суходаев \\ Ирина С. Райкова \\ Сибирский федеральный университет \\ Красноярск, Российская Федерация
}

\begin{abstract}
Аннотация. Разработана экспериментальная установка для квазистатических измерений пьезомодулей $d_{i j k}$ на основе возможностей прецизионных изменений механических напряжений прибором DMA 242 C в диапазоне частот 0-100 Гц. В измерительной схеме применен специальный держатель образцов и усилитель заряда. Выполнены измерения значений пьезомодулей тригональных пьезоэлектриков $\mathrm{La}_{3} \mathrm{Ga}_{5} \mathrm{SiO}_{14}$ (P321) and $\mathrm{YAl}_{3}\left(\mathrm{BO}_{3}\right)_{4}$ (R32). Результаты исследований коррелируют с данными других авторов.
\end{abstract}

Ключевые слова: пьезоэлектрические модули, квазистатический метод, мультиферроики. 